\title{
Evaluasi teknologi pencahayaan untuk ruangan kelas pada Pondok Pesantren Khairul Ummah
}

\author{
Azriyenni ${ }^{\circledR}$, Amir Hamzah, Riski Febriyursandi, Fri Murdiya ${ }^{\circledR}$, dan Nurhalim \\ Universitas Riau \\ *azriyenni@eng.unri.ac.id
}

\begin{abstract}
Abstrak. Pencahayaan dalam ruangan belajar yang baik akan menciptakan kenyamanan disetiap kegiatan adalah hal yang sangat baik. Pemasangan dan ketersediaan titik lampu dan jenis lampu yang baik dan tepat dapat mempengaruhi kondisi pencahayaan dalam sebuah ruangan. Permasalahannya adalah pemasangan titik lampu dan jenis lampu yang tidak sesuai dengan standar telah ditetapkan di Indonesia, dan ianya akan menyebabkan kerugian kepada manusia berupa gangguan pada fungsi mata. Tujuan pengabdian kepada masyarakat ini adalah untuk meningkatkan penerangan dan teknologi pencahayaan yang baik pada beberapa ruangan belajar (kelas) di MA dan MTs Pondok Pesantren Khairul Ummah. Kemudian, meningkatkan kualitas penerangan dan pencahayaan pada ruang belajar berbasis perangkat lunak. Metode yang akan dijalankan dalam pengabdian kepada masyarakat ini adalah mendesain dan teknik pencahayaan yang baik menggunakan perangkat lunak DIALux evo 8.1.
\end{abstract}

Kata kunci: evaluasi; lampu; pencahayaan; ruangan belajar

\begin{abstract}
Lighting on an excellent classroom will create comfort in every activity is very important. The installation and availability of light points and types of views that are good and right can affect the lighting conditions in a classroom. The problem is the installation of lights and types of lights that are not following the standards used in Indonesia, and it will cause harm to humans in the form of disturbances in eye function. The purpose of this community service is to improve proper lighting technology in several classes in MA and MTs of the Islamic Boarding School at Khairul Ummah. Then, improve the quality of light and lighting in a few the classroom based on software. The method that will be implemented in this community service is designing and techniques of lighting that are good using the software, namely DIALux Evo 8.1.
\end{abstract}

Keywords: evaluation; light; lighting; classroom

To cite this article: Azriyenni, A. Hamzah, R. Febriyursandi, F. Murdiya, \& Nurhalim. 2019. Evaluasi teknologi pencahayaan untuk ruangan kelas pada Pondok Pesantren Khairul Ummah. Unri Conference Series: Community Engagement 1: 277-285 https://doi.org/10.31258/unricsce.1.277-285

(C) 2019 Authors

Peer-review under responsibility of the organizing committee of Seminar Nasional Pemberdayaan Masyarakat 2019 


\section{PENDAHULUAN}

Pencahayaan yang baik akan menunjang keberlangsungan kegiatan di dalam suatu ruangan. Sekolah merupakan lembaga pendidikan yang menjadi wadah tempat siswa menerima dan mendapatkan ilmu pengetahuan. Ruang kelas merupakan bagian utama dalam pelaksanaan kegiatan belajar dan mengajar yang dilakukan oleh guru dan murid. Sebagian kegiatan yang dilakukan oleh murid dilakukan didalam ruangan, baik berupa belajar, berdiskusi maupun hanya untuk tempat melepaskan lelah diwaktu jam istirahat.

Pondok Pesantren Khairul Ummah merupakan salah satu lembaga pendidikan ruang lingkup pesantren terbesar di kabupaten Indragiri Hulu. Terletak di desa Batu Gajah kecamatan Pasir Penyu sehingga masyarakat tidak asing dengan lembaga pendidikan ini. Untuk tempat tinggal, murid pada tingkat pendidikan SMP/MTs hingga SMA/MA di lembaga ini diharuskan menetap di dalam asrama pondok pesantren ini, sehingga kegiatan murid tidak hanya belajar di sekolah diwaktu pagi hingga sore namun juga di waktu malam.

Pelaksanaan kegiatan di malam hari tidak kalah padatnya terhadap kegiatan di siang hari, di malam-malam tertentu seperti pada malam minggu, para murid memiliki aktivitas pendidikan pesantren berupa kegiatan Muhadharah. Kegiatan muhadharah merupakan kegiatan yang dapat melatih beberapa keahlian, diantaranya keahlian berpidato baik dalam bahasa Indonesia, bahasa Arab, maupun bahasa inggris, keahlian dalam bersenandung, membaca ayat suci Al-qur'an dan lain sejenisnya. Ruang kelas menjadi salah satu tempat yang dijadikan murid-murid untuk melaksanakan kelas, dimana pelaksanaan kegiatan ini dimulai setelah ibadah sholat isya. Tidak hanya kegiatan seperti muhadharah saja yang memerlukan ruang kelas sebagai tempat melaksanaan kegiatan, dilain itu ruang kelas juga digunakan sebagai tempat untuk kembali belajar mempelajari materi-materi yang diterima pada kegiatan siang hari ataupun belajar menghadapi perlombaan-perlombaan yang akan dilaksanakan. Sehingga tujuan dalam pelaksanaan kegiatan pengabdian kepada masyarakat ini diantara, yaitu untuk mengetahui kualitas pencahayaan pada ruang belajar, memberikan saran kepada pemilik sekolah untuk melakukan perbaikan dan penataan pencahayaan pada ruang kelas.

\section{MASALAH}

Dalam meningkatkan kualitas pendidikan, faktor pencahayaan ruang merupakan salah satu faktor yang mendukung dalam meningkatkan kualitas pendidikan. Permasalahan adalah ingin meningkatkan kualitas pencahayaan ruangan belajar dengan minimnya jumlah lampu dalam ruangan. Hal-hal demikian yang menyebabkan penyebaran pencahayaan dalam ruangan belajar tidak merata. Akibat yang ditimbulkan dari kekurangpedulian terhadap sarana pencahayaan menyebabkan gangguan syaraf mata. Lampu sebagai pencahayaan buatan tidak hanya pada dasar terangnya saja, namun pencahayaan buatan yang optimal dapat memiliki peran dalam hal menciptakan keindahan, memperbaiki suasana hati penghuni ruang, membentuk persepsi dan juga memisahkan ruang (Alisa, 2016). Pencahayaan yang optimal juga dapat mendukung fungsi ruangan, menjaga kesehatan pengguna ruang, dan menciptakan kesan ruang lebih luas (Alexander, 2019). Gambar 1 adalah menunjukkan keadaan ruangan belajar (kelas) di Sekolah MTs PP. Khairul Ummah. Berikut adalah rincian permasalahan yang dihadapi dalam pelaksanaan pengabdian:

1. Pemilihan warna permukaan ruang kelas yang beragam.

2. Jumlah lampu yang terpasang terhadap titik lampu yang tersedia.

3. Jumlah fluks cahaya (lumen) setiap lampu yang digunakan.

4. Susunan pemasangan lampu.
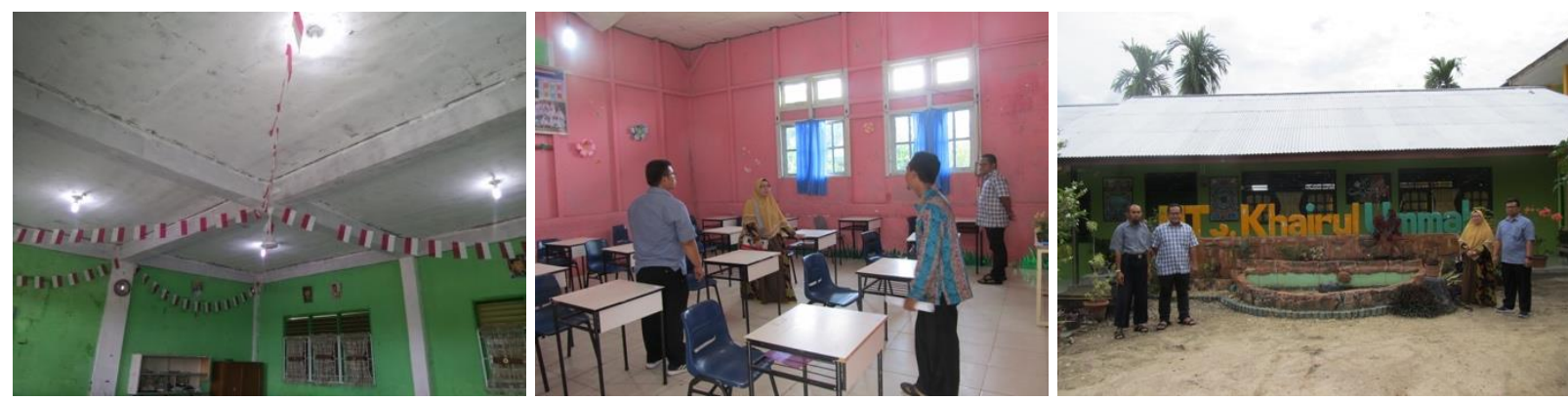

Gambar 1. Keadaan ruang kelas MTs PP. Khairul Ummah 


\section{METODE PENERAPAN}

Dalam memperbaiki kondisi pencahayaan yang ada pada ruangan belajar di MTs dan MA Pondok Pesantren Khairul Ummah, perangkat lunak DIALux evo 8.1 digunakan untuk merancang sistem pencahayaan ruangan dalam pengabdian masyarakat ini. Dalam melaksanakan perancangan perbaikan sistem pencahayaan pada ruang belajar ini dibutuhkan beberapa data, diantaranya ukuran ruangan seperti panjang, lebar dan tinggi ruangan jenis lampu, besar fluks cahaya (lumen) yang dihasilkan, faktor pemeliharaan, penentuan nilai reflektansi permukaan yang akan digunakan dalam memperbaiki kondisi pencahayaan.

1. Pengukuran Intensitas Pencahayaan

Pengukuran intensitas pencahayaan dilakukan untuk mengetahui kondisi pencahayaan yang sudah ada. Prosedur pengukuran intensitas pencahayaan mengikuti standar SNI 16-7062-2004, dimana dalam penentuan titik ukur dipengaruhi oleh luas ruangan. Metode pengukuran dilakukan dengan menentukan objek pengukuran yaitu objek meja, sedangkan titik pengukuran ditentukan oleh titik potong horizontal panjang dan lebar ruangan pada setiap jarak tertentu setinggi objek pengukuran dari permukaan lantai. Luas ruangan menyebabkan jarak pengukuran tidak sama.

a. Ruangan yang memiliki luas kurang dari 10 meter persegi, titik potong garis horizontal panjang dan lebar ruangan adalah pada jarak setiap 1 meter.

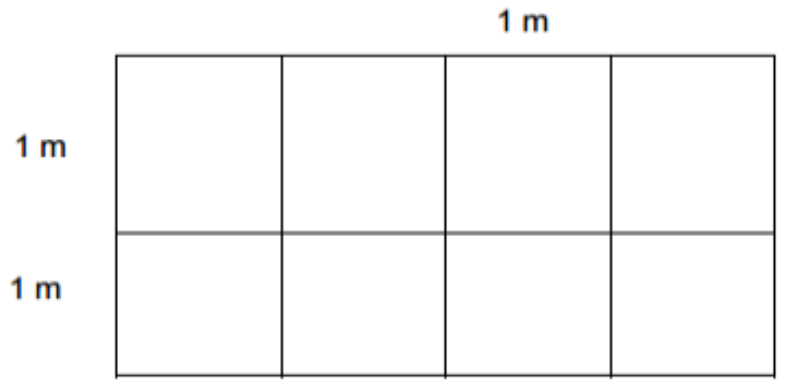

Gambar 2 Penentuan titik pengukuran dengan luas kurang dari $10 \mathrm{~m}^{2}$

b. Ruangan yang memiliki luas diantara $10 \mathrm{~m}^{2}$ hingga $100 \mathrm{~m}^{2}$, titik potong garis horizontal panjang dan lebar ruangan adalah pada jarak setiap 3 meter.

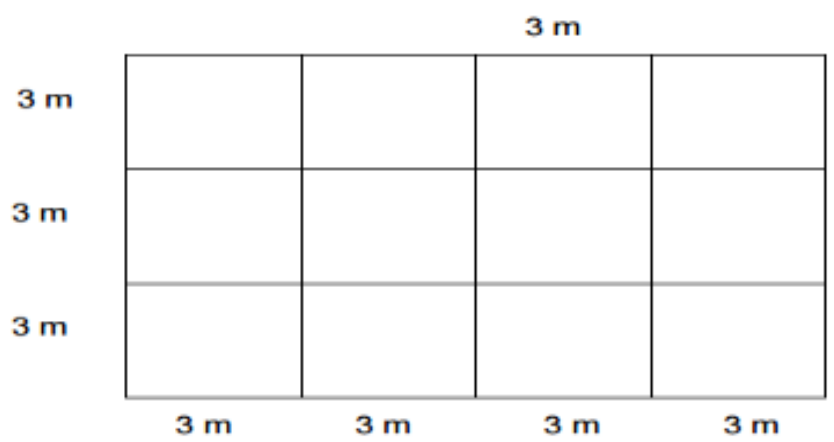

Gambar 3 Penentuan titik pengukuran dengan luas diantara $10 \mathrm{~m}^{2}$ hingga $100 \mathrm{~m}^{2}$

2. Ruangan yang memiliki luas lebih dari 100 meter persegi, titik potong garis horizontal panjang dan lebar ruangan adalah pada jarak setiap 6 meter. 


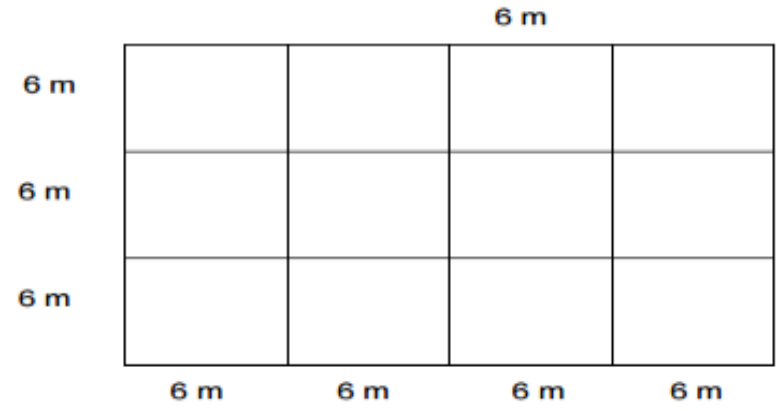

Gambar 4 Penentuan titik pengukuran dengan luas lebih dari 100 meter persegi

3. Perancangan sistem pencahayaan berbasis perangkat lunak DIALux evo 8.1

Perangkat lunak DIALux evo 8.1 digunakan untuk mendesain dan merancang sistem pencahayaan pada ruang belajar. Mengetahui jumlah luminer yang dibutuhkan pada ruang belajar dan mendapat pencahayaan yang merata. Prosedur perancangan menggunakan perangkat lunak akan dijabarkan sebagai berikut:
a. Rancang ukuran ruangan yang dijadikan objek
b. Pilih warna atau jenis material permukaan (langit-langit, dinding dan lantai
c. Pilih peralatan pendukung ruangan (kursi, meja, lemari dan lain-lain)
d. Pilih luminer yang digunakan
e. Masukkan data dari luminer yang digunakan
f. Menentukan objek perhitungan (bidang permukaan)
g. Lakukan perhitungan (set calculation- entire project)

\section{HASIL DAN KETERCAPAIAN SASARAN}

Beberapa ruangan yang diuji dan dilakukan perbaikan yaitu ruang kelas XII IPA 2 milik MA PP. Khairul Ummah dan ruang kelas D milik MTs PP. Khairul Ummah. Dari data tersebut, hasil pengukuran langsung menggunakan light meter dapat dilihat pada Tabel 2.

Tabel 1. Data Ruang kelas D

\begin{tabular}{|c|c|c|c|c|c|c|c|c|c|}
\hline \multirow{2}{*}{\multicolumn{3}{|c|}{$\begin{array}{l}\text { Ukuran Ruangan } \\
\quad \text { (meter) }\end{array}$}} & \multirow{3}{*}{ Luas } & \multicolumn{6}{|c|}{ Kondisi Eksisting } \\
\hline & & & & \multirow{2}{*}{$\begin{array}{l}\text { Lampu } \\
\text { terpasang }\end{array}$} & \multirow{2}{*}{$\begin{array}{l}\text { Jumlah } \\
\text { titik lampu }\end{array}$} & \multicolumn{4}{|c|}{ Spesifikasi Lampu } \\
\hline $\mathrm{P}$ & $\mathrm{L}$ & $\mathrm{T}$ & & & & Merek & Jenis & $\begin{array}{c}\text { Fluks } \\
\text { Cahaya }\end{array}$ & $\begin{array}{l}\text { Daya } \\
\text { (watt) }\end{array}$ \\
\hline 7,88 & 6,83 & 3,7 & 53,82 & 4 & 4 & Visalux & Flouresen & 1080 & 18 \\
\hline
\end{tabular}

Tabel 2. Hasil pengukuran langsung menggunakan light meter untuk kelas D

\begin{tabular}{ccccccccccccccccc}
\hline \multicolumn{11}{c}{ Titik Pengukuran (lux) } \\
1 & 2 & 3 & 4 & 5 & 6 & 7 & 8 & 9 & 10 & 11 & 12 & 13 & 14 & 15 & 16 & Rata- \\
rata
\end{tabular}

Dengan hasil pengukuran langsung menggunakan light meter, tingkat pencahayaan pada kelas D belum mencapai standar yang direkomendasikan, dimana menurut SNI 6197:2011 intensitas pencahayaan minimal untuk ruang kelas yaitu sebesar 350 lux. Oleh karena kurangnya tingkat pencahayaan pada ruang tersebut, penulis melakukan perbaikan untuk kelas tersebut. Dalam hal ini penulis memilih jenis lampu LED karena jenis ini lebih hemat dari lampu jenis lainnya. Berikut hasil perancangan menggunakan perangkat lunak DIALux evo 8.1. Setelah desain ruangan didapatkan, maka selanjutnya memasukkan luminer yang dibutuhkan seperti yang ditampilkan pada Gambar 5 dan Gambar 6. 


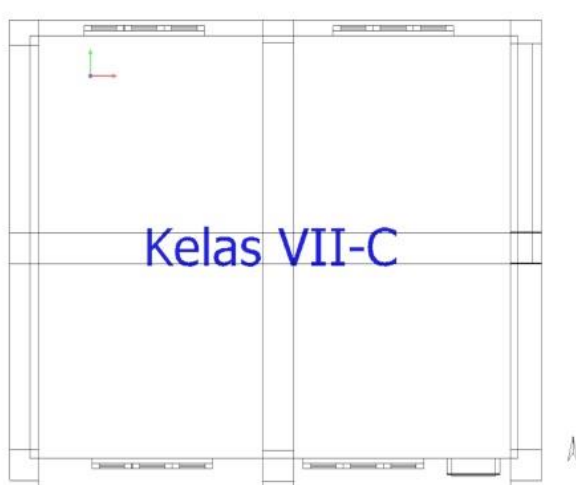

(a)

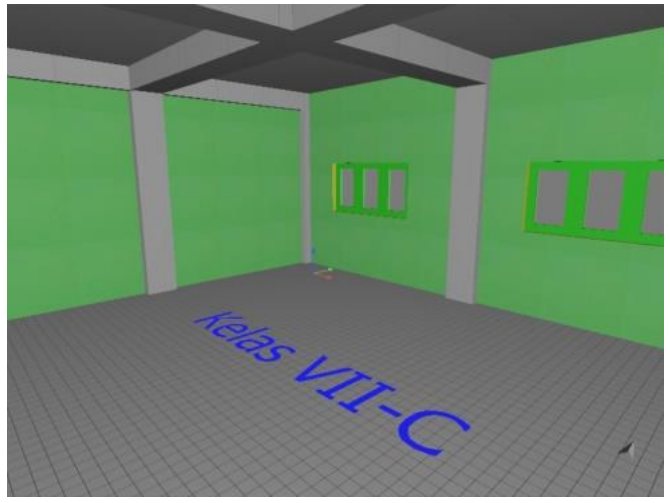

(b)

Gambar 5 Layout ruangan kelas D: (a) tampilan 2D, dan (b) tampilan 3D

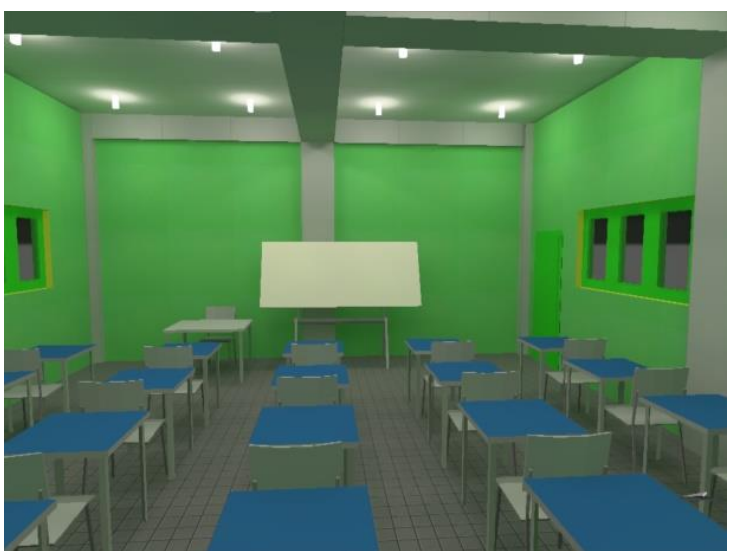

(a)

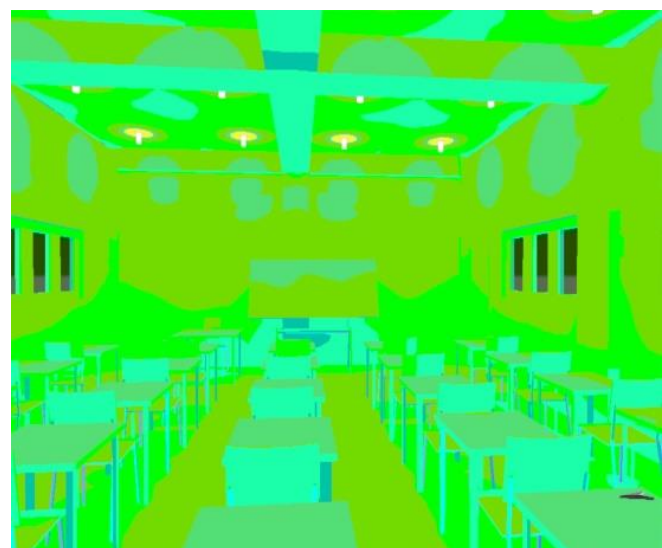

(b)

Gambar 6. Hasil simulasi ruang kelas D: (a) Suasana pencahayaan ruangan, dan (b) perbedaaan warna pada pencahayaan ruangan
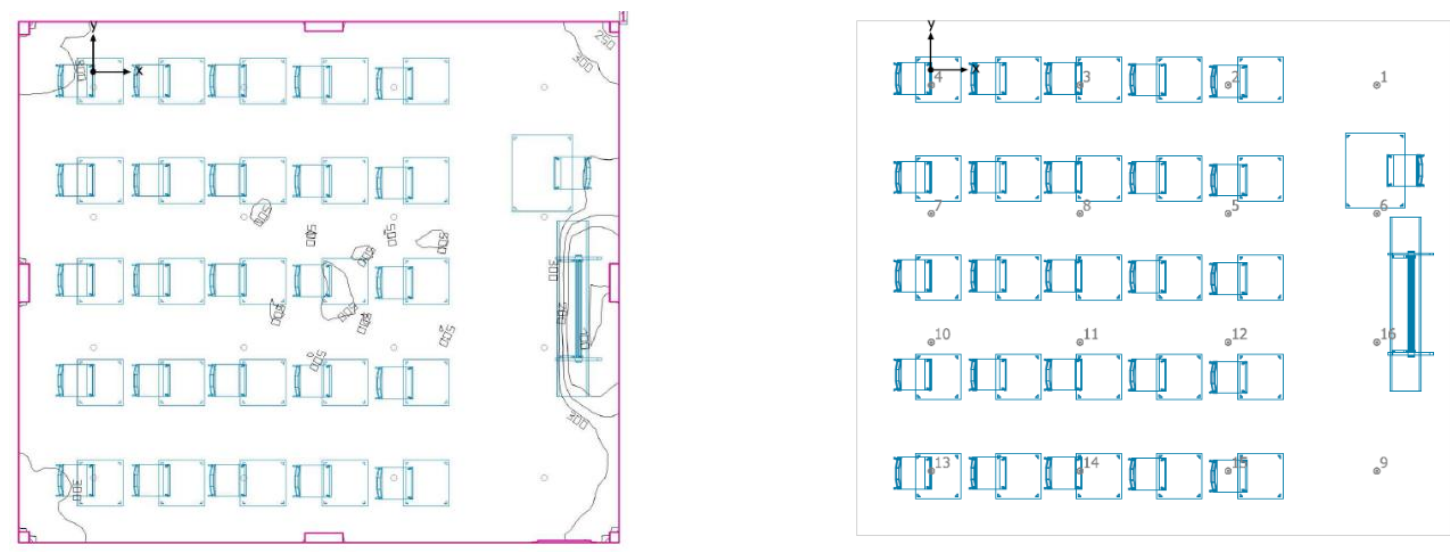

Gambar 7 Hasil Perhitungan pada Perangkat Lunak DIALux evo 8.1

Gambar 7 adalah menampilkan pencahayaan yang memenuhi standar rekomendasi, maka untuk kelas D membutuhkan pemasangan lampu sebanyak 16 titik, sehingga penyebaran cahaya menjadi rata. Spesifikasi jenis lampu yang digunakan pada perangkat lunak DIALux dapat dilihat pada Tabel 3. 
Tabel 3. Spesifikasi Lampu yang digunakan

\begin{tabular}{ll}
\hline Merek/Produksi & Philips/Philips Lighting \\
\hline Jenis Lampu & LED bulb \\
\hline Fitting & E27 \\
\hline Daya (watt) & 27 \\
\hline Suhu warna & $6500 \mathrm{~K}$ \\
\hline Fluks Cahaya (lumen) & 3000 \\
\hline Color Rendering Index (CRI) & 70 \\
\hline Frekuensi (Hz) & $50-60$ \\
\hline Tegangan (V) & $220-240$ \\
\hline
\end{tabular}

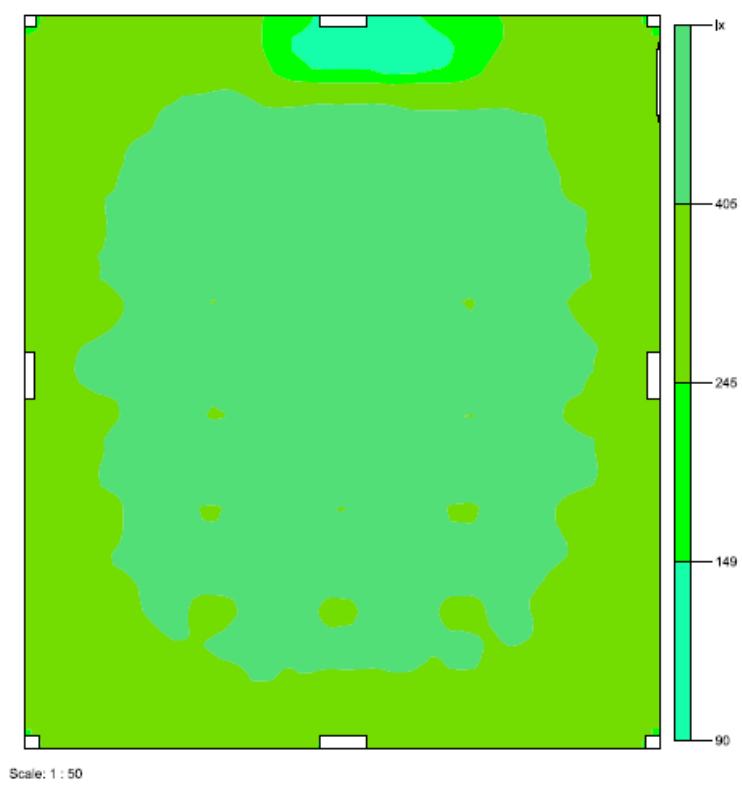

Gambar 7 Perbedaan Warna Hasil keluaran dari Simulasi DIALux evo 8.1 untuk kelas D

Tabel 4. Data ruang kelas XII IPA 2

\begin{tabular}{|c|c|c|c|c|c|c|c|c|c|}
\hline \multirow{2}{*}{\multicolumn{3}{|c|}{$\begin{array}{l}\text { Ukuran Ruangan } \\
\text { (meter) }\end{array}$}} & \multirow{3}{*}{ Luas } & \multicolumn{6}{|c|}{ Kondisi Eksisting } \\
\hline & & & & \multirow{2}{*}{$\begin{array}{l}\text { Lampu } \\
\text { terpasang }\end{array}$} & \multirow{2}{*}{$\begin{array}{l}\text { Jumlah titik } \\
\text { lampu }\end{array}$} & \multicolumn{4}{|c|}{ Spesifikasi Lampu } \\
\hline $\mathrm{P}$ & $\mathrm{L}$ & $\mathrm{T}$ & & & & Merek & Jenis & $\begin{array}{c}\text { Fluks } \\
\text { Cahaya }\end{array}$ & $\begin{array}{r}\text { Daya } \\
\text { (watt) }\end{array}$ \\
\hline 7,88 & 7,4 & 4,28 & 58,31 & 2 & 2 & Visalux & Flouresen & 2820 & 45 \\
\hline
\end{tabular}

Berdasarkan hasil simulasi menyatakan warna permukaan yang berada di tengah memiliki tingkat pencahayaan yang lebih terang daripada bagian pinggirnya. Sehingga perbaikan dengan menambah jumlah luminer hingga 16 titik dengan spesifikasi lampu yang telah disebutkan sebelumnya sudah melebihi dari rekomendasi standar yang telah ditentukan yakni minimal 350 lux untuk pencahayaan ruang kelas. Pada MA PP. Khairul Ummah, ruang yang digunakan untuk perbaikan yaitu ruang kelas XII IPS 2, ruang ini merupakan salah satu ruangan belajar dengan bentuk bangunan lama. 


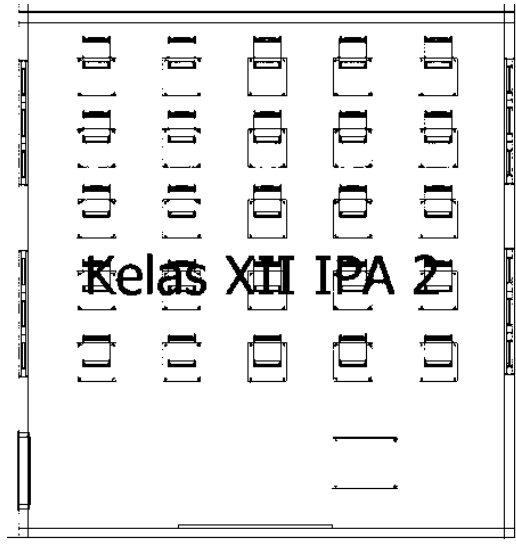

(a)

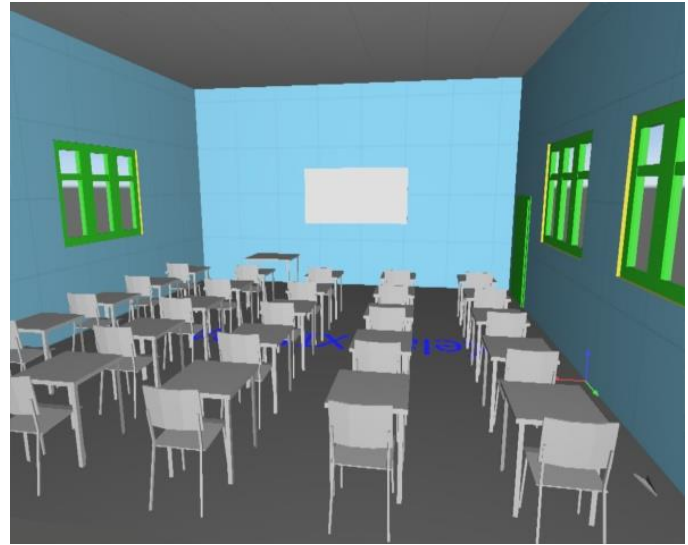

(b)

Gambar 8. Layout ruangan kelas XII IPA 2 (a) Tampilan 2D dan (b) Tampilan 3D

Tabel 5. Hasil pengukuran langsung menggunakan light meter untuk kelas XII IPA 2

\begin{tabular}{|c|c|c|c|c|c|c|c|c|c|c|c|c|c|c|c|c|}
\hline \multicolumn{16}{|c|}{ Titik Pengukuran (lux) } & \multirow{2}{*}{$\begin{array}{c}\text { Rata- } \\
\text { rata }\end{array}$} \\
\hline 1 & 2 & 3 & 4 & 5 & 6 & 7 & 8 & 9 & 10 & 11 & 12 & 13 & 14 & 15 & 16 & \\
\hline 1,2 & 31 & 30,3 & 20 & 23,4 & 42,1 & 43,8 & 26,4 & 25,1 & 43,8 & 45,6 & 27 & 20,2 & 32,3 & 34,3 & 18,4 & 22,675 \\
\hline
\end{tabular}

Setelah desain ruangan didapatkan, maka selanjutnya memasukkan luminer yang dibutuhkan.

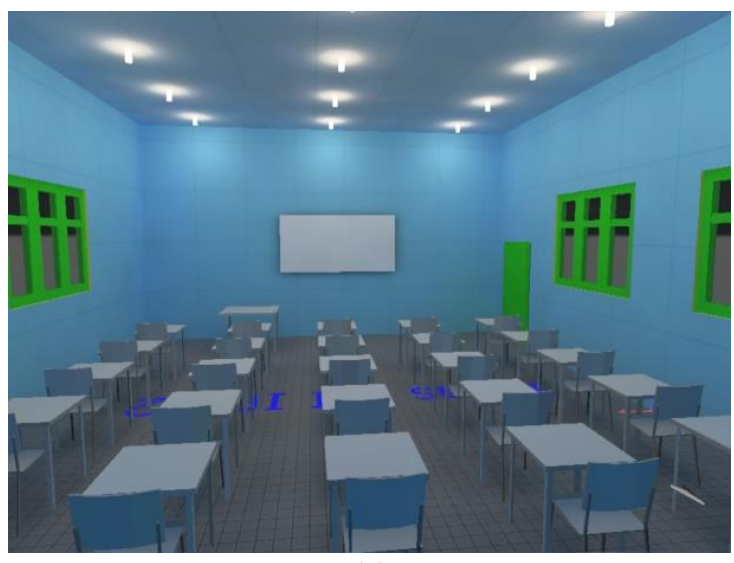

(a)

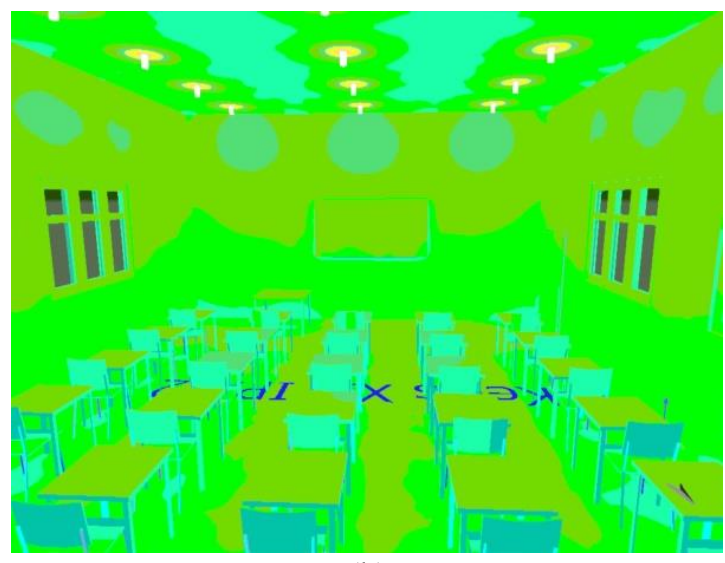

(b)

Gambar 9. Hasil Simulasi Ruang Kelas XII IPA 2: (a) Suasana pencahayaan ruangan, dan (b) Perbedaaan warna pada pencahayaan ruangan
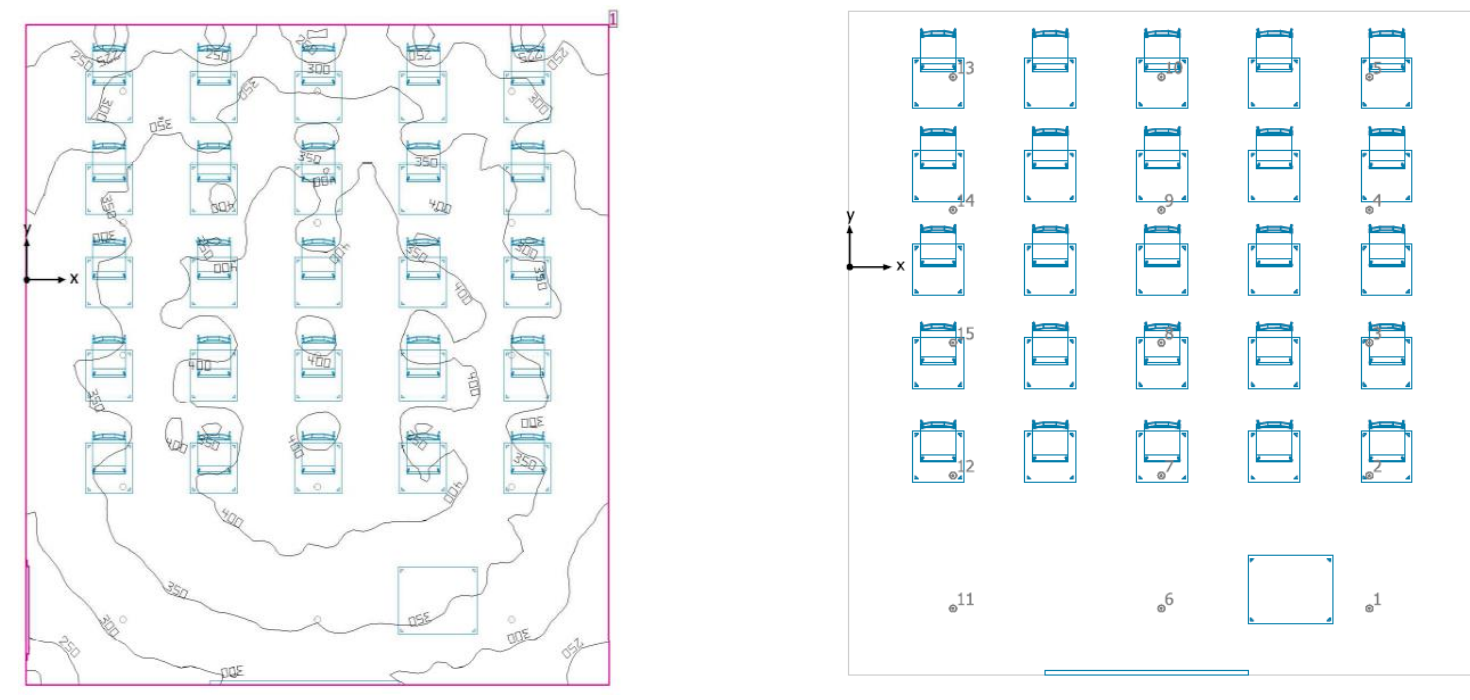


\section{Gambar 10. Hasil Perhitungan pada Perangkat Lunak DIALux evo 8.1}

Gambar 10 adalah menampilkan pencahayaan yang memenuhi standar yang direkomendasikan, maka untuk kelas XII IPA 2 membutuhkan pemasangan lampu sebanyak 15 titik, sehingga penyebaran cahaya menjadi merata. Spesifikasi jenis lampu yang digunakan pada perangkat lunak DIALux dapat dilihat pada Tabel 3. Gambar 11 merupakan tampilan hasil simulasi berdasarkan perbedaan warna, dimana pencahayaan ditengah ruangan memiliki tingkat pencahayaan yang lebih tinggi dibandingkan pencahayaan di pinggir ruangan.

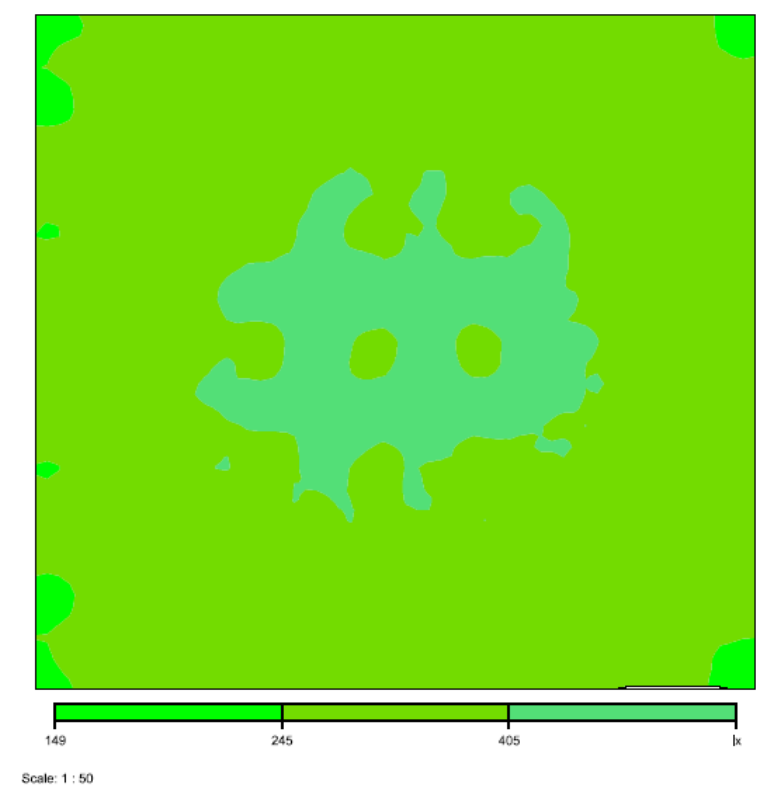

Gambar 11. Perbedaan Warna Hasil keluaran dari Simulasi DIALux evo 8.1 untuk kelas XII IPS 2

Berdasarkan hasil perhitungan dari desain yang dibuat pada perangkat lunak DIALux evo 8.1 mendapatkan hasil yang telah mencapai standar minimal rekomendasi yang dibutuhkan, dimana SNI 6197:2011 merekomendasikan pencahayaan pada lembaga pendidikan terkhusus untuk ruang kelas sebesar 350 lux. Tabel 6 memberikan perbandingan hasil dari perhitungan pada ruang kelas dan nilai standar dari SNI 6197:2011.

Tabel 6 Perbandingan hasil tingkat pencahayaan ruang belajar

\begin{tabular}{ccc}
\hline \multirow{2}{*}{ Nama Ruang } & \multicolumn{2}{c}{ Tingkat Pencahayaan (lux) } \\
\cline { 2 - 3 } & Rekomendasi SNI 6197:2011 & Hasil Perhitungan DIALux evo 8.1 \\
\hline Kelas XII IPA 2 & 350 & 351 \\
Kelas VII C (D) & 350 & 400 \\
\hline
\end{tabular}

Tabel 6 menunjukkan tingkat pencahayaan untuk ruang kelas XII IPA 2 telah mencapai standar yang direkomendasikan yaitu 351 lux, sedangkan untuk ruang kelas VII C mendapatkan hasil tingkat pencahayaan sebesar 400 lux. 


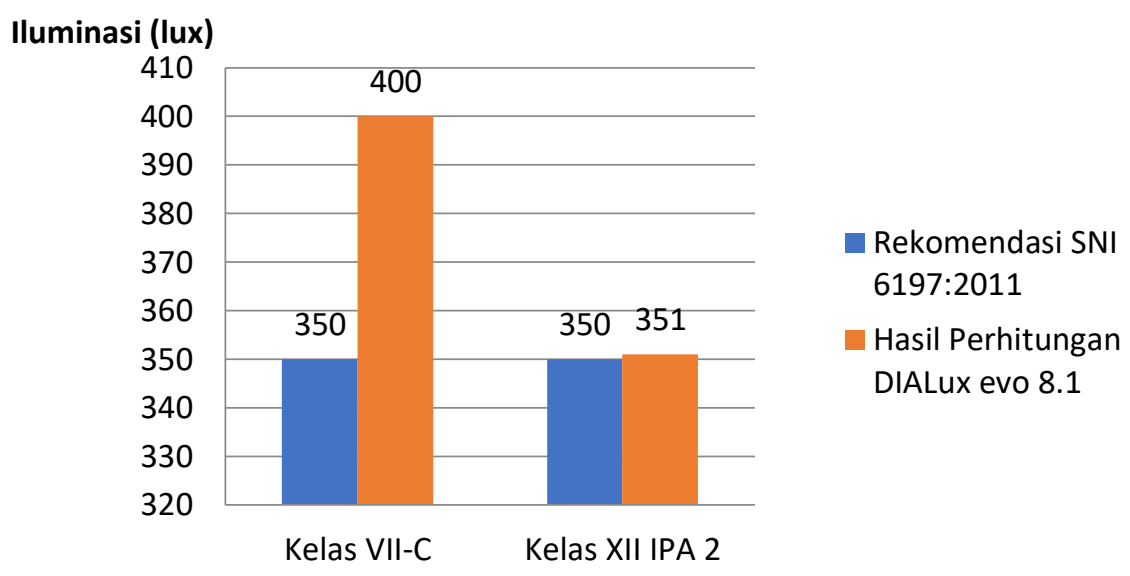

Gambar 12. Grafik Perbandingan Hasil Perhitungan terhadap minimal rekomendasi SNI 6197:2011

\section{KESIMPULAN}

Berdasarkan hasil perhitungan kemudian dimasukkan kedalam simulasi pada perangkat lunak DIALux evo 8.1, maka untuk mendapatkan hasil pencahayaan yang merata dan memenuhi standar yang ditetapkan mengacu pada standar SNI 6197:2011 untuk ruang kelas XII IPS 2, dibutuhkan jumlah titik luminer sebanyak 15,12 titik atau diambil sebanyak 15 titik lampu sedangkan pada ruang kelas D (kels VII-C) dibutuhkan jumlah titik luminer sebanyar 12,93, namun karena jenis ruangan untuk kelas D ini terdapat tulang bangunan pemasangan luminer diambil sebesar 16 titik. Warna permukaan dinding mempengaruhi kondisi pencahayaan, sehingga penulis mengambil nilai pemantulan cahaya sebesar 50\%, angka tersebut diambil dari tabel rekomendasi pemantulan dari buku Ilmu fisika Bangunan. Tidak hanya itu, warna pada permukaan dinding juga mempengaruhi suasana didalam ruang belajar.

\section{UCAPAN TERIMA KASIH}

Ucapan terima kasih LPPM UNRI yang menaja kegiatan pengabdian kepada masyarakat pada skema pengabdian DIPA UNRI 2019 yang telah dilaksanakan di Sekolah MTs PP. Khairul Ummah, Pasir Penyu, Indragiri Hilir.

\section{DAFTAR PUSTAKA}

Alexander, H. B. 2019. Penting, Terapkan Sistem Pencahayaan Optimal di Dalam Ruangan. https://properti.kompas.com/read/2019/05/18/160000521/penting-terapkan-sistem-pencahayaan-optimal-didalam-ruangan?page=1. Diakses pada 27 Juni 2019.

Alisa, S. 2016. Empat Manfaat dan Fungsi Pencahayaan dalam Rumah. http://www.tribunnews.com/lifestyle/2016/04/18/empat-manfaat-dan-fungsi-pencahayaan-dalam-rumah. Diakses pada 28 Juni 2019.

Badan Standarisasi Nasional. 2004. SNI 16-7062-2004. Pengukuran Intensitas Penerangan di Tempat Kerja.

Badan Standarisasi Nasional. 2011. SNI 6197:2011. Konservasi Energi Pada Sistem Pencahayaan. 